\title{
Record of a Mature Female Short-finned Squid, Illex illecebrosus, Captured Inshore at Newfoundland and Previous Captures of Mature Females in the Northwest Atlantic
}

\author{
E. G. Dawe and H. J. Drew \\ Department of Fisheries and Oceans, Research and Resource Services \\ P. O. Box 5667, St. John's, Newfoundland, Canada A1C 5X1
}

\begin{abstract}
A mature female short-finned squid, Illex illecebrosus, captured inshore on the west coast of Newfoundland on 26 September 1980 represents the most northerly record of a female in near-spawning condition. The specimen was classified as mature on the basis of visual examination and the nidamental gland length/mantle length ratio. Ova in the oviducts varied in size but were considerably larger than those remaining in the ovary. Fecundity was much lower than that reported for captive animals but similar to previous estimates for mature females from the wild population. The capture of the 1980 specimen is considered in relation to six previous records of mature females captured in late spring to early autumn in the Northwest Atlantic, and possible reasons for these rare occurrences are discussed.
\end{abstract}

\section{Introduction}

Biological characteristics of short-finned squid, Illex illecebrosus, have been well documented for that period of the life cycle between their first occurrence on the continental shelf in May-June and their disappearance from inshore areas and the continental shelf in November. Earlier stages of the life cycle during Febrary-April in the Northwest Atlantic have recently been described (Amaratunga et al., MS 1980; Fedulov and Froerman, MS 1980; Dawe et al., MS 1981). However, little data have been collected during the December-January period which is believed to encompass such critical stages in the life cycle as final maturation and spawning (Squires, 1967).

The process of maturation in males is better understood than in females because males reach advanced stages of maturity during their summer-autumn residence in inshore waters and on the continental shelf (Squires, 1967; Mercer, MS 1973). Recently, observations on maturation and spawning, as well as embryonic and early larval development, have been recorded and fecundity has been estimated for shortfinned squid maintained in captivity (Durward et al., 1979, 1980; O'Dor et al., MS 1980). Also, a scale of maturity stages has been developed for females and an index of maturity has been proposed for use in field studies (Durward et al., 1979).

In this paper, the first reported observation of a mature female short-finned squid from Newfoundland coastal waters is described. Ova sizes and fecundity are given and records of previous captures of females in advanced stages of maturity are reviewed. The index of maturity for these specimens, based on the relationship between nidamental gland length and mantle length, is compared with that developed from laboratory observations.

\section{Materials and Methods}

A mature female short-finned squid was found in a sample from a commercial catch by Japanese-type mechanical jigger on 26 September 1980 at Cox's Cove, Bay of Islands, Newfoundland (Fig. 1). The sample was immediately frozen and thawed later for examination in the laboratory. Length and weight measurements of the thawed specimen were recorded to the nearest $\mathrm{mm}$ and $0.01 \mathrm{~g}$ respectively. Ova sizes were measured to the nearest $0.01 \mathrm{~mm}$ using an ocular micrometer fitted to a binocular dissecting microscope. Mean sizes of ova from ovary and oviducts were calculated from measurements of 35 ova from each organ. Fecundity was estimated from counts of three $100 \mathrm{mg}$ samples of ova from the oviducts, thus making the estimate comparable to those reported by Durward et al. (1979) for females which matured in captivity. Such an estimate, which excludes the smaller eggs embedded in ovarian tissue in the ovary, is therefore only a partial estimate of the total number of ova present in the gonad.

Data pertaining to previous captures of mature females in the Northwest Atlantic were taken from original detailed sampling sheets and cruise reports (Mercer, MS 1969; unpublished data of Northwest 
Atlantic Fisheries Center, St. John's, Newfoundland). These specimens were caught during bottom trawl surveys by the Canadian vessels A. T. Cameron (1968 and 1969) and Newfoundland Hawk (1978) and the French vessel Cryos (1973). Only the specimens that were positively identified as IIlex illecebrosus were considered, as some catches included IIlex oxygonius and Illex coindetii. All measurements were performed on fresh specimens. Mantle length was recorded to the nearest $0.5 \mathrm{~cm}$ and nidamental gland length to the nearest millimeter. Data were also available on ova diameter for the specimen captured in May 1973 (Mercer and Paulmier, MS 1974).

\section{Results}

The location of capture of the mature female shortfinned squid on 26 September 1980 is the most northern of any of the previously reported captures of similar specimens (Fig. 1, Table 1). A specimen obtained on 19 August 1969 was captured in close proximity to the 1980 specimen but it had not attained such an advanced stage of maturity. Each of the specimens was in a more advanced stage of maturation than is observed in late-autumn samples from the commercial fishery. The specimen taken in May 1973 and two of the

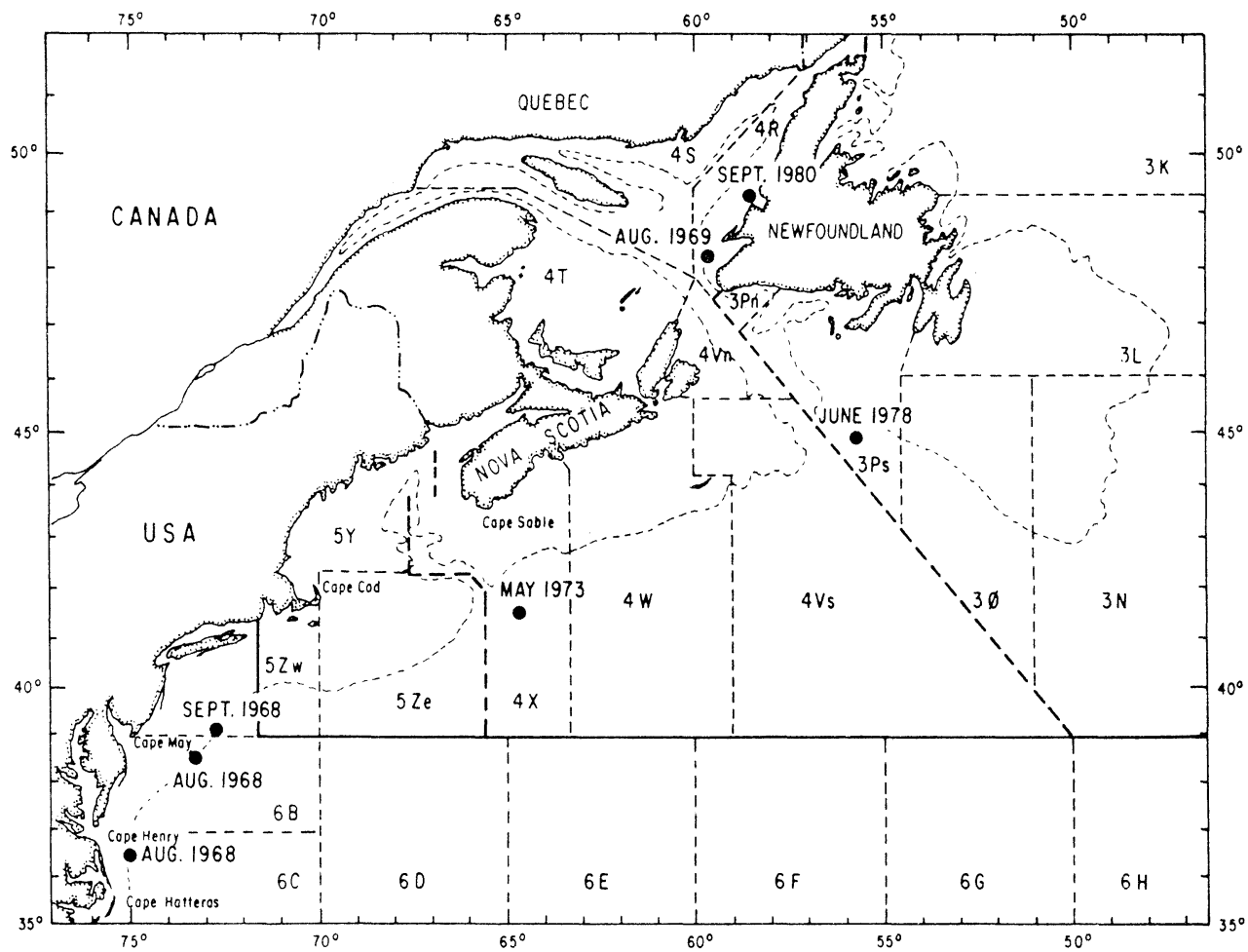

Fig. 1. Locations of capture of mature female short-finned squid in the Northwest Atlantic.

TABLE 1. Historical captures of female /llex illecebrosus in advanced stages of maturity. (Assignment of maturity stages based on NGL/ML ratio proposed by Durward ot al. (1979).)

\begin{tabular}{ccccccc}
\hline \hline Year & Date & $\begin{array}{c}\text { Location of } \\
\text { capture }\end{array}$ & $\begin{array}{c}\text { Mantle } \\
\text { length } \\
(\mathrm{mm})\end{array}$ & $\begin{array}{c}\text { Nidamental } \\
\text { gland length } \\
(\mathrm{mm})\end{array}$ & $\begin{array}{c}\text { NGL/ML } \\
\text { ratio }\end{array}$ & $\begin{array}{c}\text { Maturity } \\
\text { stage }\end{array}$ \\
\hline 1980 & $26 \mathrm{Sep}$ & $49^{\circ} 07^{\prime} \mathrm{N}, 58^{\circ} 05^{\prime} \mathrm{W}$ & 244 & 115 & 0.47 & $\mathrm{~V}$ \\
1978 & $7 \mathrm{Jun}$ & $44^{\circ} 56^{\prime} \mathrm{N}, 55^{\circ} 40^{\prime} \mathrm{W}$ & 235 & 77 & 0.33 & $\mathrm{IV}$ \\
1973 & $12 \mathrm{May}$ & $42^{\circ} 24^{\prime} \mathrm{N}, 64^{\circ} 52^{\prime} \mathrm{W}$ & 305 & 132 & 0.43 & $\mathrm{~V}^{\mathrm{a}}$ \\
1969 & $19 \mathrm{Aug}$ & $48^{\circ} 14^{\prime} \mathrm{N}, 59^{\circ} 46^{\prime} \mathrm{W}$ & 205 & 63 & 0.31 & $\mathrm{IV}$ \\
1968 & $28 \mathrm{Aug}$ & $38^{\circ} 33^{\prime} \mathrm{N}, 73^{\circ} 17^{\prime} \mathrm{W}$ & 235 & 89 & 0.38 & $\mathrm{~V}^{\text {a }}$ \\
1968 & $28 \mathrm{Aug}$ & $36^{\circ} 31^{\prime} \mathrm{N}, 76^{\circ} 29^{\prime} \mathrm{W}$ & 260 & 62 & 0.24 & $\mathrm{IV}$ \\
1968 & $6 \mathrm{Sep}$ & $39^{\circ} 00^{\prime} \mathrm{N}, 72^{\circ} 48^{\prime} \mathrm{W}$ & 255 & 105 & 0.41 & $\mathrm{~V}^{\text {a }}$ \\
\hline
\end{tabular}

${ }^{a}$ Spermatophores present in mantle cavity. 
three specimens captured in August 1968 off the United States coast had mated, as indicated by the presence of spermatophores in the mantle cavity.

The September 1980 specimen was described as mature on the basis of visual examination (Fig. 2). The nidamental glands were greatly enlarged, white and firm. The oviducal glands were swollen and the oviducts and ovary were yellow and also enlarged. Ova were loose in the mantle cavity upon dissection. Oblate spherical ova in the oviducts ranged in diameter (major and minor axes) from $0.76 \times 0.69 \mathrm{~mm}$ to $1.63 \times 1.09 \mathrm{~mm}$, the average size being $0.88 \times 0.75 \mathrm{~mm}$. Ova from the ovary were smaller, ranging from $0.29 \times 0.22 \mathrm{~mm}$ to 0.69 $\times 0.30 \mathrm{~mm}$ with mean size of $0.38 \times 0.26 \mathrm{~mm}$.

The oviducts contained $19.27 \mathrm{~g}$ of ova in various stages of development, representing $12 \%$ of the total weight of the specimen. There were $188 \pm 8.34$ ova (mean \pm standard deviation) per $100 \mathrm{mg}$ sample from the oviducts, giving a mean fecundity estimate of 36,288 ova. The gonad weight (ovary, oviducts and oviducal glands) was $52.16 \mathrm{~g}$ and the body weight was $155.84 \mathrm{~g}$. The ratio of gonad weight to body weight $(0.34)$ is greater than the minimum ratio $(0.09)$ indicated by Durward $\theta t$ al. (1979) for stage $V$ from their study on captive animals.

The ratio of nidamental gland length (NGL) to mantle length $(\mathrm{ML})$ for the seven specimens ranged from 0.24 to 0.47 , the highest value being for the 1980 specimen (Table 1). According to the index of maturity proposed by Durward et al. (1979), the maturity of the 1980 specimen and the three females which had mated corresponds to stage $\mathrm{V}(\mathrm{NGL} / \mathrm{ML}>0.35)$ and that of the remaining three specimens to stage IV.

\section{Discussion}

The capture of a mature female short-finned squid on 26 September 1980 represents the first record of a female in such an advanced stage of maturity from Newfoundland inshore waters. The location of this and the only previous capture of a maturing female so early in the season on the west coast of Newfoundland suggests that acceleration of sexual maturation may be associated with higher water temperatures in that area than are prevalent in other coastal areas. Beck ot al. (MS 1981) found that males from the west coast were more mature than those from other areas of insular Newfoundland. Mercer (MS 1973) noted that areal differences in the rate of maturation of males may be due to variation in temperature.

If spawning occurs in January-February (Squires, 1967), the mature females captured in May-September either matured atypically very early in the season or are survivors from the previous winter spawning. However,

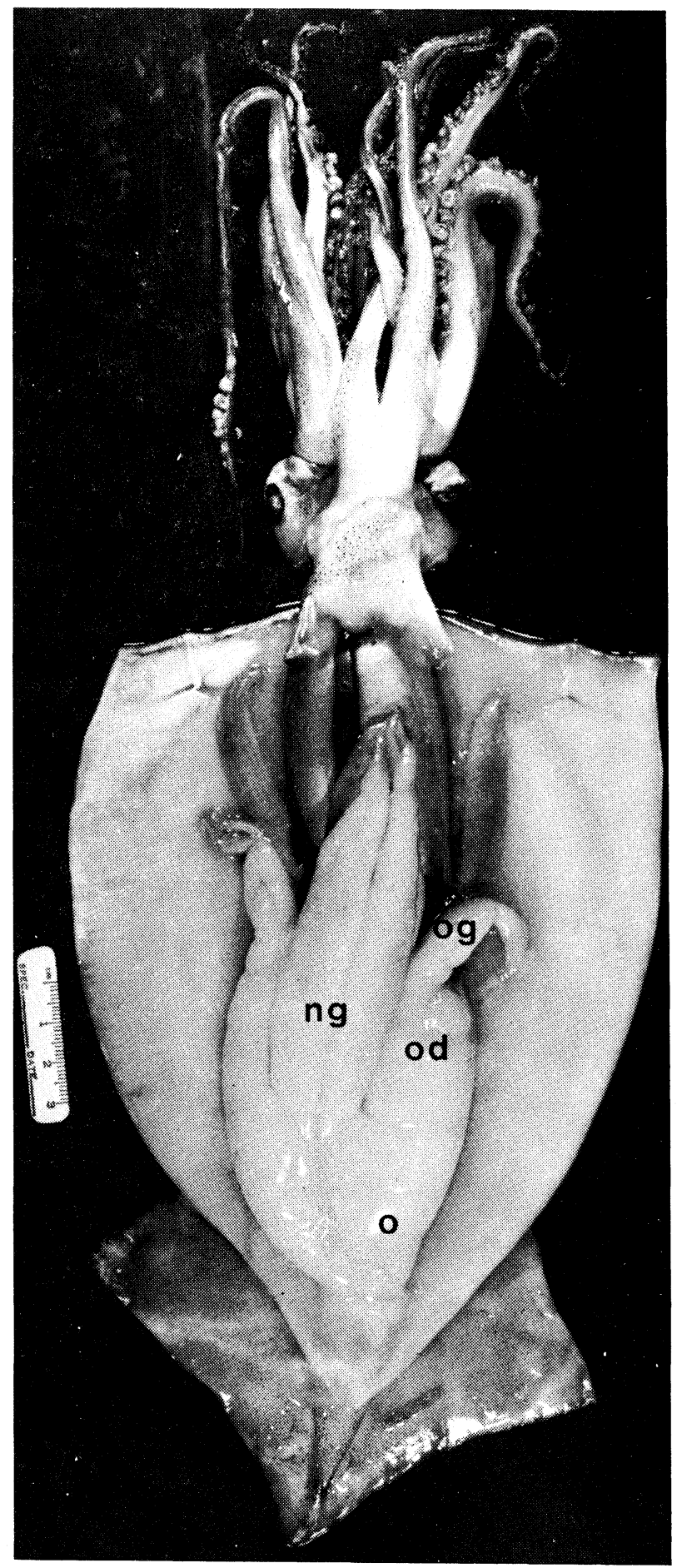

Fig. 2. Mature femaie short-finned squid captured on 26 September 1980 in Bay of Islands. Newfoundland. ( $\mathrm{ng}=$ nidamental gland, od = oviduct, og = oviducal gland, o = ovary.)

if protracted spawning occurs off the United States coast (Lange, MS 1981), the mature females captured in Subarea 6 during late August-early September may 
actually be indicative of some autumn spawning in that area. However, these captures may not be indicative of the time of peak spawning but could reflect nonuniform seasonal sampling effort, as few surveys have been conducted in this area later in the year. Durward et al. (1980) noted that occurrence of mature females in late spring and summer is so rare that they are more likely to be oddities rather than a part of the normal breeding population.

Because of its large size and high index of maturity, the specimen taken in May 1973 probably matured and mated during the preceding winter but did not spawn. The mean size of ova in this specimen was $0.9 \times$ $0.6 \mathrm{~mm}$ (Mercer and Paulmier, MS 1974). Squires (1957) reported the capture on Grand Bank in May 1953 of two large females with ova diameters of 1.00 and $0.83 \mathrm{~mm}$, which he (pers. comm.) indicated to be maximum diameters. These animals probably matured in the preceding winter but did not spawn.

The fecundity estimate for the September 1980 specimen $(36,288$ ova) is much lower than that reported for captive females $(400,000$ ova) (Durward et al., 1979) but similar to estimates $(31,100$ and 39,400 ova) for two smaller mature females captured in Subarea 6 in late May 1975 (Lipinski, MS 1979). It is possible that the fecundity of the September 1980 specimen may be underestimated, as freezing may have caused some of the eggs to rupture (R. K. O'Dor, pers. comm.), but close agreement with Lipinski's estimates indicates that fecundity in the wild population may be much lower than that estimated from captive females (Durward et al., 1979). Fecundity of $I$. illecebrosus is probably related to the number of completely developed ova in the oviducts at the time of spawning (O'Dor et al., MS 1980), but it may be lower in that some ova may remain in the oviducts after spawning (Durward et al., 1980). Therefore, partial fecundity based on the number of ova in the oviducts may better represent the spawning potential of a female than total fecundity based on all ova in the gonad. Large uniform ova and high fecundity of captive females probably reflect atypical maturation in the absence of males. O'Dor et al. (MS 1980) noted that fertilized captive females had many more incompletely developed ova remaining in the ovary than did mature females which were maintained in the absence of males. The presence of males is believed to serve as the spawning stimulus (O'Dor et al., MS 1980).

Classification of the 1980 specimen as maturity stage $V$, based on the gonad weight/body weight and nidamental gland length/mantle length ratios, agrees with the subjective classification based on visual examination. Also, all three females with spermatophores in the mantle cavity were classified as stage $\mathrm{V}$ by the nidamental gland length/mantle length ratio. Thus, although the unavailability of data for all stages of the maturation process has precluded exact definition of maturity stages, the index of maturity proposed by Durward et al. (1979) appears to be applicable to specimens from the wild population.

\section{Acknowledgements}

The authors thank M. C. Mercer and G. V. Hurley who previously worked at the St. John's Biological Station and scientists of the Institute Scientifique et Technique des Peches Maritimes, Saint Pierre et Miquelon, under whose supervision the specimens were captured at different times. Thanks are also extended to P. W. Collins, W. R. Squires and P. C. Beck who participated in the cruises, to C. C. Lu who positively identified the specimens, to $H$. Mullett and G. King for preparation of the illustrations, and to J. A. Moores who kindly reviewed the manuscript.

\section{References}

AMARATUNGA, T., T. ROWELL, and M. ROBERGE. MS 1980. Summary of joint Canada/USSR research program on short-finned squid (Illex illecebrosus), 16 February to 4 June 1979: spawning stock and larval survey. NAFO SCR Doc., No. 38, Serial No. N069.

BECK, P. C., E. G. DAWE, and J. DREW. MS 1981. Breakdown of squid (IIlex illecebrosus) catches in NAFO Subarea 3 and Division 4R in 1980 , with length and sex composition from Newfoundland inshore commercial samples and early season offshore areas. NAFO SCR DOC., No. 27, Serial No. N306.

DAWE, E. G., P. C. BECK, and H. J. DREW. MS 1981. Distribution and biological characteristics of young short-finned squid (IIlex illecebrosus) in the Northwest Atlantic, February 20-March 11, 1981. NAFO SCR Doc., No. 23, Serial No. N302.

DURWARD, R. D., T. AMARATUNGA, and R. K. O'DOR. 1979. Maturation index and fecundity for female squid, llex illecebrosus, (LeSueur, 1821). ICNAF Res. Bull., No. 14: 67-72.

DURWARD, R. D., E. VESSEY, R. K. O'DOR, and T. AMARATUNGA. 1980. Reproduction in the squid, Illex illecebrosus: first observation in captivity and implications for the life cycle. ICNAF Sel. Papers, No. 6: 7-13.

FEDULOV, P. P., and Yu. M. FROERMAN. MS 1980. Effect of abiotic factors on distribution of young shortfin squids, Illex illecebrosus (LeSueur, 1821). NAFO SCR Doc., No. 98, Serial No. N153.

LANGE, A. M. T. MS 1981. Evidence of summer spawning of Illex illecebrosus (LeSueur) off the northeastern USA. NAFO SCA Doc., No. 33, Serial No. N315.

LIPINSKI, M. MS 1979. Universal maturity scale for the commerciallyimportant squids (Cephalopoda: Teuthoidea): the results of maturity classification of the Illex illecebrosus (LeSueur, 1821) populations for the years 1973-77. ICNAF Res. Doc., No. 38, Serial No. 5364.

MERCER, M. C. MS 1969. A. T. Cameron Cruise 150, otter-trawl survey of the mid-Atlantic Bight, August-September 1968. Fish. Res. Bd. Canada Tech. Rep., No. 122; 47 p.

MS 1973. Sexual maturity and sex ratios of the ommastrephid squid, Illex illecebrosus (LeSueur), at Newfoundland (Subarea 3). ICNAF Res. Doc., No. 71, Serial No. 3023.

MERCER, M. C., and G. PAULMIER. MS 1974. Distribution and biological characteristics of the short-finned squid (IIlex illecebrosus) on the continental shelf of Subareas 3 and 4 in May-June 1973. ICNAF Res. Doc., No. 87, Serial No. 3323. 
O'DOR, R. K., E. VESSEY, and T. AMARATUNGA. MS 1980. Factors affecting fecundity and larval distribution of squid, Illex illecebrosus. NAFO SCR Doc., No. 39, Serial No. N070.

SQUIRES, H. J. 1957. Squid, Illex illecebrosus (LeSueur), in the New- foundland fishing area. J. Fish. Res. Bd. Canada, 14: 693-728. 1967. Growth and hypothetical age of the Newfoundland bait squid, Illex illecebrosus illecebrosus. J. Fish. Res. Bd. Canada, 24: 1209-1217. 
